\title{
Originals
}

\section{Cell cycle and gene expression in the insulin producing pancreatic cell line $\beta \mathrm{TC1}$}

\author{
B. Bréant, C. Lavergne and G. Rosselin \\ Unité INSERM 55, Hôpital Saint-Antoine, Paris, France
}

\begin{abstract}
Summary. The pancreatic cell line $\beta T C 1$, established from insulinomas of transgenic mice carrying a hybrid insulin-promoted large $\mathrm{T}$ antigen gene, has retained several characteristics of normal cells, including the insulin content and inducibility of insulin secreting by glucose. We show here that the growth of $\beta \mathrm{TC} 1$ cells is arrested in low serum-concentration medium. Cells exposed for three days to $0.25 \%$ fetal calf serum ceased to incorporate $\left[{ }^{3} \mathrm{H}\right]$ thymidine but were still able toresume the cell division cycle upon addition of serum. In this cell line, we have determined by cytofluorometry the cell cycle kinetic parameters to be of $21 \mathrm{~h}, 10 \mathrm{~h} 30 \mathrm{~min}$ and $12 \mathrm{~h}$ for the $\mathrm{G}_{1}, \mathrm{~S}$ and $\mathrm{G}_{2} / \mathrm{M}$ phases, respectively. Quiescent $\beta \mathrm{TC} 1$ cells constitutively expressed the protooncogene $c-j u n$ that codes
\end{abstract}

for the transcriptional factor AP1, as well as cdc2, another cell cycle-related gene. A large transient increase in the expression of the c-fos gene was obtained rapidly, 30 min after addition of serum and a similar increase in $c-j u n$ expression after one hour. Expression of the cdc2 gene was also enhanced to a lesser extent. The same effects were also observed in the presence of cycloheximide, thus proving that the expression of these three genes is directly stimulated by serum growth factors. Consequently, quiescent $\beta \mathrm{TC} 1$ cells provide a good model for studying the short- and long-term effects of growth factors on Beta-cell proliferation.

Key words: Beta cell growth, cell cycle, oncogenes.
It is of crucial importance to understand the mechanisms which control the Beta-cell mass, since the insulin deficiency observed in Type 1 (insulin-dependent) diabetes mellitus is associated with the destruction of insulin-secreting cells and little is known about the mechanism of Beta-cell renewal. Most of the studies on G1 events and regulation of cell proliferation have been carried out with fibroblasts and with haematopoietic cells [1]. The results show that the regulation of cell proliferation differs according to the cell type. In the pioneering work of Swenne [2], the analysis of the Beta-cell cycle was approached using fetal islets cultured in vitro. Fetal Beta cells were shown to have a high proliferative capacity [2]. Those results and the finding that Beta cells can be induced to reenter the cell cycle by appropriate environmental signals [3] represented a considerable advance in the understanding of Beta-cell function. The recent development of insulin-producing cell lines such as those obtained from hamster insulinoma tumours (HIT cells) [4], from rat insulinoma (RIN cells) [5], rat transplantable islet cell tumour (CRI cells) [6] or SV40 T-Antigen transgenic mouse (IgSV195) [7] provides remarkable new models for the study of Beta-cell regulation. We have used the $\beta T C 1$ cell line recently established by Efrat et al. [8] from insulinomas of transgenic mice carrying a hybrid insulin-gene: large $T$ antigen of simian virus 40 under the control of the rat insulin II promoter; this cell line retains morphological characteristics of pancreatic Beta cells. $\beta \mathrm{TC} 1$ cells were shown to synthesize and release insulin [8] and to stimulate DNA synthesis upon glucose stimulation [9]. In this work we have determined the conditions under which BTC1 cells become quiescent through depletion of serum and the subsequent resumption of the cell division cycle upon external stimulation.

\section{Materials and methods}

\section{Materials}

Dulbecco's modified minimum essential medium (DMEM) was obtained from Intermed (Noisy le Grand, France). Fetal calf serum (FCS) was from Boehringer Mannheim (Meylan, France). $\left[{ }^{3} \mathrm{H}\right]$ thymidine was purchased from Amersham (Les Ulis, France). Plateletderived growth factor was obtained from Collaborative Research Inc, (Bedford, MA, USA). Other chemicals were of reagent grade.

\section{Cell culture}

BTC1 cells were kindly supplied by D.Hanahan and routinely cultured in DMEM medium ( $25 \mathrm{mmol} / \mathrm{l}$ of glucose) supplemented with $8 \%$ FCS, $100 \mathrm{U} / \mathrm{ml}$ penicillin and $100 \mathrm{mg} / \mathrm{ml}$ streptomycin. They were plated at about $10 \%$ confluence and passed once a week when 


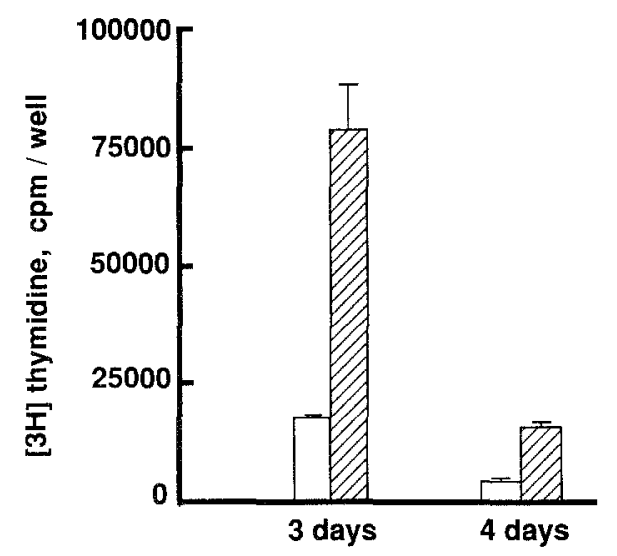

Fig. 1. Arrest of $\beta T C 1$ cell growth in medium containing a low serum concentration. Serum deprivation was allowed to proceed for 3 or 4 days in $0.25 \%$ fetal calf serum Dulbecco's modified minimum essential medium. Cells were then submitted to serum stimulation ( $8 \%$ fetal calf serum, hatched bars) or medium change (open bars) in the presence of $\left[{ }^{3} \mathrm{H}\right]$ thymidine $(1 \mu \mathrm{Ci} / \mathrm{ml})$ for the following $24 \mathrm{~h}$. The incorporated radioactivity was determined as described in Materials and methods. Results are means and SEM of triplicate determinations of a representative experiment

they reached about $50 \%$ confluence, as recommended by Efrat et al. [8]. The medium was changed every two to three days. We have ensured that $\beta T C 1$ cells retain their ability to respond to glucose by insulin secretion [8]. During all experiments the glucose concentration was kept to $25 \mathrm{mmol} / 1$.

\section{Measurement of the rate of DNA synthesis}

For studies of mitogenic effects, cells were seeded in Corning 24-well dishes (180000 cells/well in $1 \mathrm{ml}$ volume) in medium supplemented with $8 \% \mathrm{FCS}$. The cells were washed twice with $1 \mathrm{ml}$ of serum-free medium $24 \mathrm{~h}$ after seeding. The latter was replaced with a medium containing $0.25 \%$ fetal calf serum for three days, unless otherwise stated. After serum deprivation, the cells were stimulated by serum or mitogenic factors in the presence of $\left[{ }^{3} \mathrm{H}\right]$ thymidine $(1 \mu \mathrm{Ci})$ for the following $24 \mathrm{~h}$. Incorporation of the labelled precursor into DNA was terminated by adding three drops of $1 \mathrm{~mol} / \mathrm{l}$ ascorbic acid [10]. Cells were washed twice with cold phosphate-buffered saline (PBS), twice with cold $5 \%$ trichloroacetic acid (TCA), and solubilized in $0.3 \mathrm{ml}$ of $0.1 \mathrm{~mol} / \mathrm{l} \mathrm{NaOH}, 0.1 \% \mathrm{SDS}$. An aliquot $(0.25 \mathrm{ml})$ of the solubilized cells was mixed with $5 \mathrm{ml}$ of Aqualyte Scintillation Liquid (JT Baker B. V., Deventer, The Netherlands) and counted in an LKB beta-spectrometer.

\section{Analysis of RNA}

For RNA extraction, $25 \cdot 10^{6}$ cells were seeded in $100 \mathrm{~mm}$ Petri dishes $\left(5 \cdot 10^{6} \mathrm{cells} / \mathrm{dish}\right)$. Twenty four hours after seeding, the cells were washed twice with serum-free medium and rendered quiescent by incubation in $0.25 \% \mathrm{FCS}$-containing medium for three days. After the treatment described in the figure legends, cells were chilled on ice, washed once with cold PBS and total RNA was isolated using the $\mathrm{Li}-\mathrm{Cl}$ /urea precipitation procedure described by Auffray and Rougeon [11]. Twenty micrograms of total RNA was denatured in $2.2 \mathrm{~mol} / /$ formaldehyde for $10 \mathrm{~min}$ at $60^{\circ} \mathrm{C}$, fractionated by electrophoresis in formaldehyde $2.2 \mathrm{~mol} / \mathrm{l}$ agarose $1 \%$ gel, transferred onto a nitrocellulose filter, fixed by heating at $80^{\circ} \mathrm{C}$ and hybridized overnight at $42^{\circ} \mathrm{C}$ with ${ }^{32} \mathrm{P}$-labelled probes (labelled by Multiprime, (Amersham) to a specific activity of $2-4 \cdot 10^{\circ} \mathrm{dpm} / \mu \mathrm{g}$ ) in $5 \times$ SSPE,
$5 \times$ Denhardt's, $0.1 \%$ SDS and $50 \%$ formamide, according to Maniatis et al. [12]. The blots were then washed twice in $2 \times \mathrm{SSC}, 0.1 \%$ $\mathrm{SDS}$ for $15 \mathrm{~min}$ at room temperature, for $1 \mathrm{~h}$ at $45^{\circ} \mathrm{C}$ in the same buffer and then for $30 \mathrm{~min}$ in $0.1 \times \mathrm{SSC}, 0.1 \%$ SDS at $45^{\circ} \mathrm{C}$. Blots were exposed to X-ray films (Kodak XAR5) with intensifying screens (Dupont Cronex type Quanta III, Euromedica, Paris, France) at $-80^{\circ} \mathrm{C}$. Exposure time varied from overnight to five days.

\section{Probes}

The probes were rat $\alpha$-tubulin cDNA [13]; BgI II-Pvu II fragment of FBJ provirus (v-fos) [14]; 3rd exon of human c-myc probe [15]; mouse cde 2 cDNA (kindly provided by P.Nurse) and RJA1 clone corresponding to mouse c-jun cDNA [16].

\section{Flow cytometry analysis (FCM)}

Exponentially growing cells $\left(10 \cdot 10^{6}\right.$ cells $)$ were stained in the culture dish for $1 \mathrm{~h}$ with $5 \mu \mathrm{g} / \mathrm{ml}$ Hoechst 33342 (Sigma, La Verpillière, France) at $37^{\circ} \mathrm{C}$ in standard culture medium [17]. After washing in PBS buffer containing $1.5 \mathrm{mmol} / \mathrm{l}$ EDTA, cells were harvested with trypsine-EDTA, washed again with the PBS-EDTA buffer and suspended at a density of $10^{6}$ cells per $\mathrm{ml}$ in DMEM medium containing $2 \% \mathrm{FCS}$ and $1.5 \mathrm{mmol} / 1 \mathrm{EDTA}$. Immediately prior to FCM analysis cells were filtered through a $37 \mu \mathrm{m}$ nylon monofilament mesh filter. The fluorescence of the stained cells was monitored on a FACS 440 (Becton Dickinson, Mountain View, CA, USA) interfaced to a MCA 3000 computer (Bruiker, Wissembourg, France). The excitation was with the $365 \mathrm{~nm}$ line of a Spectra Physics mode1 20-20 argon ion laser, and emission was measured using a $450 \mathrm{~nm}$ long pass filter and $450 \mathrm{~nm}$ Oriel band pass filter. Three synchronisations of exponentially growing cells were performed in the cell sorter and two populations were sorted in each synchronisation: 1 . cells in $G_{1}$ and in $S$, 2. cells in $\mathrm{G}_{1}$ and in $\mathrm{G}_{2} / \mathrm{M}$ and 3. cells in $\mathrm{S}$ and in $\mathrm{G}_{2} / \mathrm{M}$. The three fluorescence profiles obtained were strictly superimposable to each other. They were analysed according to the Fox model [18]. The sorted cells were collected in $20 \%$ FCS, DMEM medium under sterile conditions and replated in $35 \mathrm{~mm}$ Petri dishes $\left(10^{5} \mathrm{cells} / \mathrm{dish}\right)$. The replated cells were again stained with Hoechst 33342 for $1 \mathrm{~h}$ in the culture dish, collected and filtered as described above before FCM analysis. A control calibration histogram with exponentially growing cells was performed $24 \mathrm{~h}$ after the first synchronization at this lower cellular density (5 to $10 \cdot 10^{4}$ cells $/ \mathrm{ml}$ ); this histogram was perfectly superimposable with those obtained in the three synchronizations (not shown). FCM analysis was performed 7, 10,11,14, 18 and $21 \mathrm{~h}$ after replating the cells synchronized in $\mathrm{G}_{1} ; 7,9$ and $10 \mathrm{~h} 30 \mathrm{~min}$ for the cells synchronized in the $S$ phase; $6,7,10$ and $12 \mathrm{~h}$ for the cells synchronized in $G_{2} / M$. Only three representative points are presented in the Results.

\section{Results}

\section{Arrest of $\beta T C 1$ cell growth in medium containing low serum concentrations}

Serum deprivation for two to three days was required to arrest $\beta$ TC1 cell growth (Fig. 1). Cells exposed for three days to $0.25 \%$ FCS ceased to incorporate $\left[{ }^{3} \mathrm{H}\right]$ thymidine but could resume their cell division cycle during the following $24 \mathrm{~h}$ upon serum addition. Incubating the cells for an additional day in the serum-depleted medium led to a dramatic decrease in $\left[{ }^{3} \mathrm{H}\right]$ thymidine incorporation for the following $24 \mathrm{~h}$, in control cells as well as in serum stimulated cells (Fig.1). Cell viability was $>90 \%$ in the serum- 


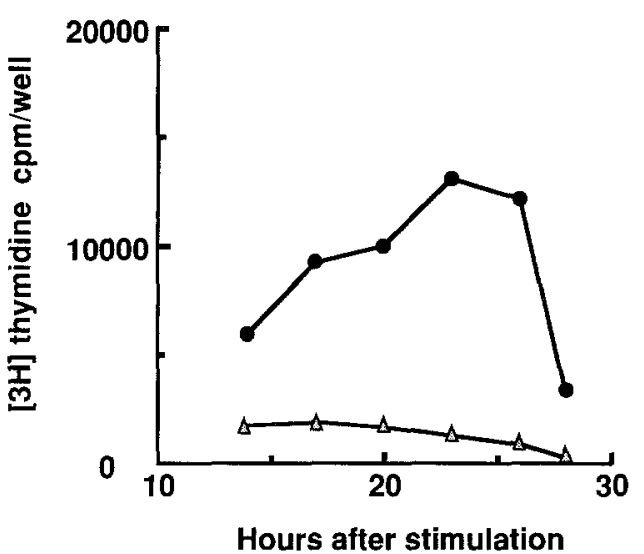

Fig. 2. Effect of serum on DNA synthesis in $\beta T C 1$ cells. Cells were rendered quiescent by a 3-day incubation in low serum containing medium. The medium was then replaced (zero time) with an $8 \%$ fetal calf serum Dulbecco's modified minimum essential medium (FCS DMEM) (black circles) or for control cells, with a $0.25 \%$ FCS DMEM medium (open triangles). After $14 \mathrm{~h},\left[{ }^{3} \mathrm{H}\right]$ thymidine pulses $(2 \mu \mathrm{Ci} / \mathrm{ml})$ of $2 \mathrm{~h}$ duration were applied every $3 \mathrm{~h}$. The incorporated radioactivity was determined as described in Materials and methods. The data shown are means of duplicate values and are represented at the mean times of thymidine pulse application

G1 PHASE

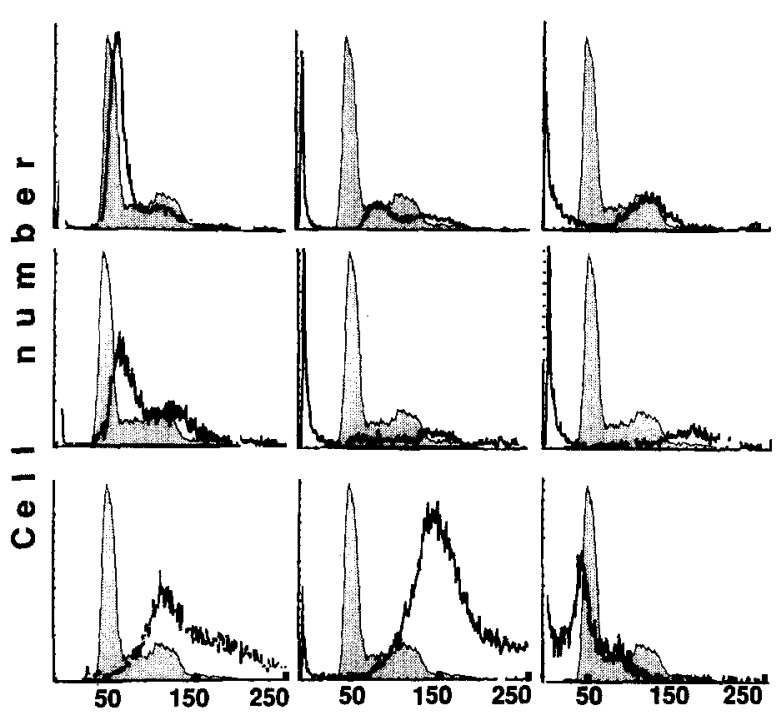

Channel number (relative fluorescence intensity)

Fig. 3. $\beta \mathrm{TC} 1$ cell cycle kinetics. Exponentially growing $\beta \mathrm{TC} 1$ cells were synchronized in a cell sorter in the various cycle phases as described in Materials and methods and replated for various periods of time. Only three representative points are presented for each phase of the cell cycle. The distribution of the fluorescence of the cell population shown by black lines corresponds to the replated cells; the initial distribution of the asynchronous population is presented in grey. Left: $G_{1}$ phase, 7,10 and $21 \mathrm{~h}$ from top to bottom. Middle: $S$ phase, 7,9 and 10 h 30 min from top to bottom. Right: $G_{2} / M$ phase, 6, 7 and $12 \mathrm{~h}$ from top to bottom

depleted medium until the end of the fourth day of incubation, i.e. three days of deprivation plus one day in the presence of $\left[{ }^{3} \mathrm{H}\right]$ thymidine (data not shown). Cells starved of serum for three days were thus defined as quiescent cells in the following experiments.
The time dependence of $\left[{ }^{3} \mathrm{H}\right]$ thymidine incorporation is shown in Figure 2. The stimulation of $\left[{ }^{3} \mathrm{H}\right]$ thymidine incorporation was already detected $14 \mathrm{~h}$ after serum addition, maximal stimulation being observed at $23 \mathrm{~h}$. The incorporation decreased afterwards. In the control cells the $\left[{ }^{3} \mathrm{H}\right]$ thymidine incorporation remained very low throughout the experiment (Fig.2). As described by Swenne, the width of the first DNA synthetic wave (measured at a height of $50 \%$ of the peak value), can be used as an index of the mean S phase duration [2]. In $\beta T C 1$ cells the length of the $S$ phase can be roughly estimated to about $10 \mathrm{~h}$.

\section{Kinetics of the $\beta T C 1$ cell cycle}

The duration of each phase of the $\beta \mathrm{TC} 1$ cell cycle was determined in two steps by cytofluorometry of exponentially growing cells (Fig.3). In the first step, the selected populations were synchronized in the different phases of the cell cycle and then replated (see Materials and methods). In the second step, the replated cells were analysed at different time intervals after replating. The duration of a given phase was defined as the minimum time for all the cells to leave this phase. The $G_{1}$ phase was the longest phase of the $\beta$ TC1 cell cycle (Fig. 3). Seven hours after replating, only a small number of cells had moved from the $\mathrm{G}_{1}$ to the $\mathrm{S}$ channels (Fig. $3, \mathrm{G}_{1}$, top) and after $10 \mathrm{~h}$ about $50 \%$ of the cells were still in $\mathrm{G}_{1}$ (Fig. $3, \mathrm{G}_{1}$, middle). All the cells had left the $G_{1}$ phase $21 \mathrm{~h}$ after replating (Fig. $3, \mathrm{G}_{1}$, bottom). The $\mathrm{S}$ phase was more rapid: as soon as seven hours after replating, about one-third of the population had shifted to the $\mathrm{G}_{2} / \mathrm{M}$ channels (Fig. 3, S, top). The S phase was completed after $10 \mathrm{~h} 30 \mathrm{~min}$ (Fig. 3, S, bottom), confirming the length of $10 \mathrm{~h}$ estimated in the $\left[{ }^{3} \mathrm{H}\right]$ thymidine experiment. Six hours after reseeding, nearly all cells synchronized in $\mathrm{G}_{2} / \mathrm{M}$ were remaining in their initial channels (Fig. 3, $\mathrm{G}_{2} / \mathrm{M}$, top) but after one additional hour, a large proportion of cells had left the $\mathrm{G}_{2} / \mathrm{M}$ channels (Fig. 3, $\mathrm{G}_{2} / \mathrm{M}$, middle). Twelve hours after replating, all the cells had left the $\mathrm{G}_{2} / \mathrm{M}$ channels and entered the next G1 phase (Fig. 3, $\mathrm{G}_{2} / \mathrm{M}$, bottom). We conclude that the lengths of the different phases of the $\beta T C 1$ cell cycle are 21 h. $10 \mathrm{~h} 30 \mathrm{~min}$ and $12 \mathrm{~h}$ for the $\mathrm{G}_{1}, \mathrm{~S}$ and $\mathrm{G}_{2} / \mathrm{M}$ phases, respectively. The complete generation time of the $\beta \mathrm{TC} 1$ cells is therefore 42 to $43 \mathrm{~h}$, which is consistent with the doubling time of $45 \mathrm{~h}$ calculated from typical growth curves (data not shown).

\section{Dispensability of platelet growth factors for $\beta T C 1$ cell growth}

In order to determine the involvement of platelet factors in the resumption of the $\beta \mathrm{TC} 1$ cell cycle, cells were rendered quiescent by serum depletion, and then submitted to various concentrations of human adult platelet-poor plasma or serum. Figure $4 \mathrm{~A}$ shows that both the serum and plasma were highly mitogenic in $\beta \mathrm{TC} 1$ cells. Their effects were similar throughout the concentration range studied $(0.25$ to $8 \%)$. Furthermore, purified plateletderived growth factor (PDGF, $1 \mathrm{U} / \mathrm{ml}$ ), in the presence of 
A

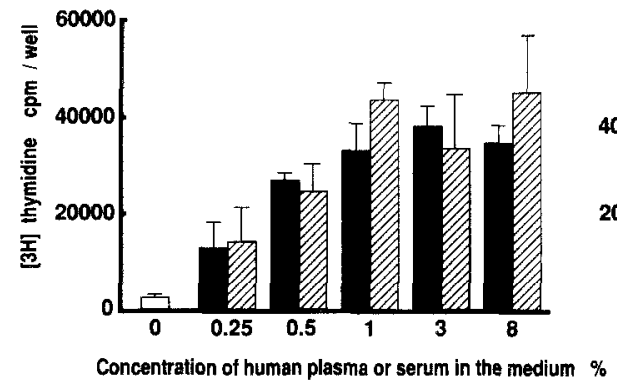

B

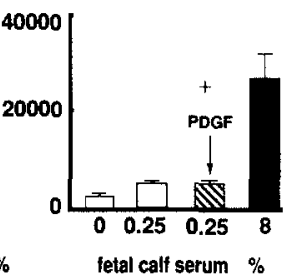

Fig.4A, B. Dispensability of platelet growth factors for $\beta \mathrm{TC1}$ cell growth. Cells were depleted of serum for 3 days as described in Materials and methods. The medium was replaced with serum-free medium, with which the cells were washed twice. Panel A: serum-free medium (open bars) or various concentrations of human plateletpoor plasma (black bars) or of the corresponding human serum (hatched bars), were then added simultaneously with $\left[{ }^{3} \mathrm{H}\right]$ thymidine $(1 \mu \mathrm{Ci} / \mathrm{ml})$ for the following $24 \mathrm{~h}$. Panel B: cells were submitted to serum-free medium or $0.25 \%$ fetal calf serum (FCS) (open bars), $0.25 \%$ FCS $+1 \mathrm{U} / \mathrm{ml}$ platelet derived growth factor (PDGF) (hatched bars) or $8 \%$ FCS (black bars) in the presence of $\left[{ }^{3} \mathrm{H}\right]$ thymidine for $24 \mathrm{~h}$. The incorporated radioactivity was determined as described in Materials and methods. Data shown are means and SEM of triplicate determinations

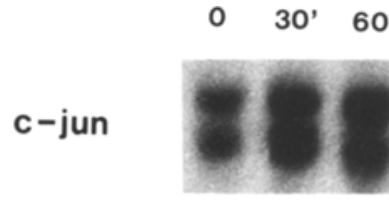

$c-$ fos

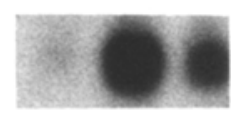

$\alpha-$ tub

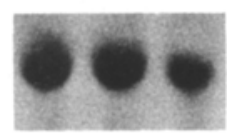

$\mathrm{cdc}_{2}$

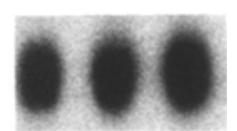

Fig.5. Expression of the cell cycle-related genes. Cells were rendered quiescent as described in Materials and methods. Total RNA was extracted, immediately, after 30 or 60 min of stimulation by $8 \%$ fetal calf serum. Twenty $\mu \mathrm{g}$ of total RNA was analysed in Northern blots and hybridized with [ $\left.{ }^{32} \mathrm{P}\right]$-labelled probes, as described in Materials and methods. Sizes of the mRNAs: c-fos $2.2 \mathrm{~kb}$ [14], c-jun $2.7 \mathrm{~kb}$ and $3.2 \mathrm{~kb}$ [16], cdc2 $1.6 \mathrm{~kb}$, and $\alpha$-tubulin $1.8 \mathrm{~kb}$ [13]. Exposure time was overnight for c-jun, $\mathrm{cdc} 2$ and $\alpha$-tubulin, and $24 \mathrm{~h}$ for $\mathrm{c}-$ fos

$0.25 \% \mathrm{FCS}$, did not induce the quiescent cells to enter the cell cycle (Fig. 4B). These results indicate that neither PDGF nor other platelet factors seem to be necessary for $\beta T C 1$ cell proliferation. Furthermore the enhancement of $\left[{ }^{3} \mathrm{H}\right]$ thymidine incorporation either with human plasma or serum vs fetal calf serum, indicates that other factors or nutrients advantageous for $\beta \mathrm{TC} 1$ cell growth, might be present in human sera.

Expression of cell cycle-related genes

The initiation of the cell division cycle is correlated to the enhanced expression of specific genes [1]. The time course for the stimulation of these cell cycle-related genes was analysed in the early phase of serum induction. RNA from quiescent $\beta T C 1$ cells was extracted immediately (lane 0 ), $30 \mathrm{~min}$ or $1 \mathrm{~h}$ after addition of serum (Fig.5). In the quiescent $\beta T C 1$ cells, the $c-j u n$ mRNA was already detectable and cdc 2 mRNA was also constitutively expressed. While no c-fos mRNA was detected in quiescent cells, a strong and fast induction of c-fos gene expression occurred in the serum-pulsed cells. Maximal levels of this mRNA were obtained after $30 \mathrm{~min}$ of stimulation and decreased thereafter. C-jun expression was enhanced at $30 \mathrm{~min}$ and then remained approximately constant during the first hour. After more than $3 \mathrm{~h}$ in the presence of serum, c-jun mRNA levels decreased to basal levels (not shown). Only a slight increase in the cdc2 mRNA level was observed after $1 \mathrm{~h}$ of treatment with serum. No change in the expression of $\alpha$-tubulin was detected under those conditions, in agreement with the stable expression of $\alpha$-tubulin gene observed in other systems during the early phases of the cell cycle [19]. The c-myc mRNA could not be detected with serum stimulations varying from $30 \mathrm{~min}$ to several hours (not shown).

Cycloheximide has been reported to superinduce several early genes by stabilizing the corresponding mRNAs and preventing the down-regulation of transcription by the protein products $[20,21]$. Furthermore, cycloheximide allows the analysis of the direct effects of serum on cell cycle-related gene expression. We therefore treated quiescent $\beta$ TC1 cells for $2 \mathrm{~h}$ with cycloheximide $(1 \mu \mathrm{g} / \mathrm{ml})$ with nothing (lane 1 ) or with $8 \%$ serum (lane 2 ). The cellular RNAs were hybridized with the radioactive probes as shown in Figure 6. The cell cycle-related genes c-fos, c-jun and cdc2 were expressed at a low level in the cycloheximide-treated cells in the absence of serum. The c-myc mRNA was hardly detectable. In addition, serum induced the accumulation of mRNA corresponding to the cell cycle-related genes c-fos and c-jun (lane 2). Superinduction by cycloheximide was also observed for the cdc2 mRNA, and was more unexpected for a gene known to be induced in the cell cycle much later than c-fos and c-jun [22]. Only a very slight induction of the c-myc mRNA occurred in the cells treated with cycloheximide and serum (lane 2).

\section{Discussion}

The data presented in this report were obtained with pancreatic $\beta T C 1$ cells. This cell line was established by Efrat [8] from insulinomas derived from transgenic mice carrying hybrid insulin-promoted SV40 large T antigen. These cells possess characteristics of differentiated normal Beta cells [8]. Although their insulin content is somewhat lower than that of Beta cells in cultured mouse islets, they have retained the glucose-induced insulin secretion and express high steady state levels of insulin mRNA $[8$, 9]. We have established the conditions of serum depletion 
1

fos

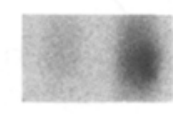

jun

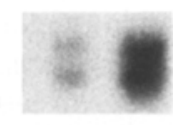

$\alpha-$ tub

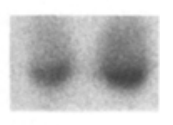

$\mathrm{cdc}_{2}$

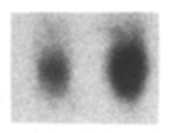

myc

Fig.6. Expression of the cell cycle-related genes in the presence of cycloheximide. Quiescent cells left for 3 days in $0.25 \%$ fetal calf serum (FCS) medium were treated for $2 \mathrm{~h}$ with $1 \mu \mathrm{g} / \mathrm{ml}$ cycloheximide (a concentration sufficient to inhibit more than $90 \%$ of protein synthesis) either alone (lane 1) or in the presence of $8 \%$ FCS (lane 2). Twenty micrograms samples of total RNA analysed by Northern blots was hybridized with the indicated radiolabelled probes, as described in Materials and methods. The exposure time was $24 \mathrm{~h}$, except for the c-myc probe: 5 days

allowing the cells to enter quiescence: when cultured for three days in medium containing $0.25 \% \mathrm{FCS}$, the $\beta \mathrm{TC} 1$ cells cease to incorporate $\left[{ }^{3} \mathrm{H}\right]$ thymidine and can be recruited into the cell division cycle upon the addition of serum. This provided a model permitting the analysis of the early events associated with $\beta \mathrm{TC} 1$ cell growth, including the expression of cell cycle-related genes. The constitutive expression of c-jun mRNA in quiescent $\beta \mathrm{TC} 1$ cells is in line with the observation of Piette et al. that in cells transformed chemically or with SV40, the synthesis of AP1, encoded by the c-jun gene, becomes independent of growth factors [23]. The expression of cdc2 at quiescence may be a consequence of SV 40 large $T$ antigen expression, probably involved in the immortalization of the initial Beta cells; alternatively, it might be linked to the additional genetic events that have led to the transformation of $\beta \mathrm{TC} 1$ cells. In $\beta \mathrm{TC} 1$ cells, the levels of the c-fos and cjun mRNA were cell-cycle dependent. It constituted an early transient response since it was detected within 30 min of serum addition. The early changes in c-fos and cjun expression correlate well with the transient character of the induction of these genes by serum in quiescent fibroblasts [21,24]. The occurrence of c-fos together with c$j u n$ as an early gene in $\beta T C 1$ cells suggests that the transcription of AP1-responsive genes triggered by the FOS/AP1 interaction [25-27] constitutes an important step in the progression of these cells towards DNA syn- thesis. In addition, we have observed that cycloheximide increased the intensity of the c-fos signal in quiescent cells, and prolonged its expression in serum-pulsed cells. This superinduction is in agreement with that observed in other cellular systems [28] and has been attributed to the stabilization of short lived c-fos mRNA [29]. The constitutive expression of the cdc2 gene, a homologue of a fission yeast cell division cycle gene, is also of interest since this gene is known to be expressed at a later stage in the cell cycle (end of the $G_{1}$ phase), its protein product becoming operational in $\mathrm{G}_{2}[22,30]$. The increase of the cdc2 signal observed in serum-pulsed cells in the presence of cycloheximide suggests that in $\beta$ TC 1 cells, the expression of the cdc2 gene might be directly regulated by growth factors. The c-myc mRNA was not detectable in quiescent or serum-stimulated cells; in the presence of cycloheximide, only a very weak induction of this mRNA was observed with serum. In contrast, c-myc has been shown to be strongly expressed in RIN cells [31]. These results suggest that the regulation of the expression of the c-myc gene does not play a pivotal role in the onset of $\beta \mathrm{TC} 1$ cell division cycle.

We have determined the $\beta \mathrm{TC1}$ cell cycle parameters to be of $21 \mathrm{~h}, 10 \mathrm{~h} 30 \mathrm{~min}$ and $12 \mathrm{~h}$ for the $\mathrm{G}_{1}, \mathrm{~S}$ and $\mathrm{G}_{2} / \mathrm{M}$ phases, respectively. The complete $\beta T C 1$ cell cycle is therefore of 42 to $43 \mathrm{~h}$. Swenne's elegant work using fetal rat islets which have a large proportion of proliferative Beta cells defined for the first time in vitro, the cell cycle kinetics of Beta cells in islets [32]. The cell cycle synchronization was achieved by treatment with hydroxyurea, a drug that collects the cells at the $G_{1} / S$ boundary. The length of the $G_{1}$ phase was $2.5 \mathrm{~h}$, of $\mathrm{S}, 6.4 \mathrm{~h}$, of $\mathrm{G}_{2}$, $5.5 \mathrm{~h}$ and of $\mathrm{M}, 0.5 \mathrm{~h}$ [32]. In the $\beta \mathrm{TC} 1$ cell line, the duration of the $S$ and $\mathrm{G}_{2} / \mathrm{M}$ phases are about twice those determined by Swenne in fetal rat islets. The discrepancy in the timing of events of the $\beta \mathrm{TC} 1$ cell cycle as compared to fetal rat islets essentially resides in the duration of the $\mathrm{G}_{1}$ phase which is about 8 to 9 times longer in the $\beta T C 1$ cells than in the fetal islets. There may be an increase in the length of the $G_{1}$ phase with age, according to Swenne [33]. Moreover, as recently reviewed by Pardee, the duration of $\mathrm{G}_{1}$ might be reduced in embryonic cells [1]. While it is not clear that one can extrapolate from fetal rat islet cells to immortalized mouse Beta cells, our results suggest that in view of the cell cycle kinetics, the $\beta \mathrm{TC} 1$ cells behave more like adult cells rather than fetal cells.

Islets in culture constitute invaluable models for identifying substances likely to be physiologically relevant, and this system has permitted the detection of the mitogenic effect of growth factors such as growth hormone $[34,35]$ and insulin-like growth factor I [36, 37]. Growth factors which are responsible for the resumption of the cell cycle in $\beta$ TC1 cells have not yet been identified. Preliminary experiments suggest that growth factor effects are not coupled to a cyclic AMP-dependent signal. The results of electroporation of fetal rat islets with several oncogene constructs by Welsh et al. [38] suggested that a mitogenic response occurred when islet cells were transfected with an oncogene (v-src) coding for a protein with a tyrosine kinase activity. PDGF is known to induce the state of competence in fibroblasts, i.e. the capacity to 
respond to platelet-poor plasma [39] and may have been a good candidate for promoting this response since Swenne et al. showed that PDGF doubled fetal rat islet DNA synthesis [40]. However, Welsh et al. have shown that adult Beta cells require transfection with the gene coding for the B-type PDGF receptor to acquire responsiveness to PDGF [41]. Accordingly, quiescent $\beta$ TC1 cells were insensitive to PDGF and responded to low concentrations of platelet-poor plasma with the same efficiency as to serum, in contrast with fibroblasts. It therefore seems unlikely that $\beta \mathrm{TC} 1$ cells require PDGF as a competence factor to progress towards DNA synthesis. Our results do not exclude however that other competence factors could be present in platelet-poor plasma. Alternatively the genetic events that have led to the transformation of $\beta T C 1$ cells may have rendered them independent of PDGF, as described for other transformed cell lines [42]. Moreover, the higher rate of $\left[{ }^{3} \mathrm{H}\right]$ thymidine incorporation either with human plasma or serum, as compared to fetal calf serum suggests that other factors or nutrients might be advantageous for $\beta \mathrm{TC} 1$ cell growth. $\beta \mathrm{TC1}$ cells obtained in the quiescent state and subsequently stimulated by growth factors, provide a good model for studying the short-term effects of purified growth factors, measured by c-fos expression, and their long-term effects measured by DNA synthesis and expression of genes appearing later in the cell cycle.

Acknowledgements. The authors are indebted to Dr D. Hanahan for providing the $\beta \mathrm{TCl}$ cell line. We gratefully acknowledge the Service de cytofluorimétrie analytique et séparative, CNRS, IRSC (Villejuif, France) and particularly Z. Mishal for flow cytometry analysis. We also wish to thank J. Mester and M.E. Forgue-Lafitte for critical reading of the manuscript, D. Lhenry for expert secretarial assistance and Y. Issoulié for prints.

\section{References}

1. Pardee AB (1989) G1 events and regulation of cell proliferation. Science 246: 603-608

2. Swenne I (1984) The cell cycle and growth regulation of pancreatic $\beta$ cells. In: Larner J, Pohl SL (eds) Methods in diabetes research, vol 1, part A. Wiley and Sons, New York Chichester Brisbane Toronto Singapore, pp 175-191

3. Hellerström C, Swenne I (1985) Growth pattern of pancreatic islets in animals. In: Volk BW, Arquilla RE (eds) The diabetic pancreas. Plenum Press, New York, pp 53-79

4. Santerre RF, Cook RA, Crisel RMD, Sharp JD, Smidt RJ, Williams DC, Wilson CP (1981) Insulin synthesis in a clonal cell line of simian virus 40-transformed hamster pancreatic beta cells. Proc Natl Acad Sci USA 78: 4339-4343

5. Gazdar AF, Chick WL, Oie HE, Sims HL, King DL, Weir GC, Lauris V (1980) Continuous, clonal, insulin- and somatostatinsecreting cell lines established from a transplantable rat islet cell tumor. Proc Natl Acad Sci USA 77: 3519-3523

6. Carrington CA, Rubery ED, Pearson EC, Hales CN (1986) Five new insulin-producing cell lines with differing secretory properties. J Endocrinol 109: 193-200

7. Gilligan A, Jewett L, Simon D, Damjanov I, Matschinsky FM, Weik H, Pinkert C, Knowles BB (1989) Functional pancreatic $\beta$ cell line from SV40 T-antigen transgenic mouse. Diabetes 38: 1056-1062

8. Efrat S, Linde S, Kofod H, Spector D, Delannoy M, Grant S, Hanahan D, Baekkeskov S (1988) Beta-cell lines derived from transgenic mice expressing a hybrid insulin gene-oncogene. Proc Natl Acad Sci USA 85: $9037-9041$

9. Bréant B, Lavergne C, Rosselin G (1989) Glucose stimulates DNA synthesis in quiescent $\beta$ TC1 cells. Diabetologia 32: 470 (Abstract)

10. Campisi J, Medrano EE, Morreo G, Pardee AB (1982) Restriction point control of cell growth by a labile protein: evidence for increased stability in transformed cells. Proc Natl Acad Sci USA 79: $436-440$

11. Auffray C, Rougeon F (1980) Purification of mouse immunoglobulin heavy messenger RNA from total myeloma tumor RNA. Eur J Biochem 107: 303-314

12. Maniatis T, Frisch E, Sambrook J (1982) Molecular cloning: a laboratory manual. Cold Spring Harbour Lab, Cold Spring Harbour, NY

13. Lemishka IR, Farmer S, Racaniello VR, Sharp PA (1981) Nucleotide sequence and evolution of a mammalian $\alpha$-tubulin messenger RNA. J Mol Biol 151: 101-121

14. Curran T, Peters G, Beveren C van, Teich N, Verma IM (1982) FBJ murine osteosarcoma virus: identification and molecular cloning of biologically active proviral DNA. J Virol 44: 674-682

15. Dalla Favera R, Gelmann EP, Martinotti S, Franchini G, Papas TS, Gallo RC, Wong-Staal F (1982) Cloning and characterization of different human sequences related to the onc gene ( $\mathrm{v}$-myc) of avian myelocytomatosis virus (MC 29). Proc Natl Acad Sci USA 79: 6497-6501

16. Ryseck RP, Hirai SI, Yaniv M, Bravo R (1988) Transcriptional activation of c-jun during the G0/G1 transition in mouse fibroblasts. Nature 334: 535-537

17. Métézeau $\mathrm{P}$ (1988) Coloration vitale spécifique de l'ADN cellulaire. In: Métézeau P, Ronot X, Le Noan-Merdrignac G, Ratinaud M-H (eds) La cytométrie en flux pour l'étude de la cellule normale ou pathologique, vol 2. Medsi Mc Graw-Hill, Paris London New York, pp 7-9

18. Fox MH (1980) A model for computer analysis of synchronous DNA distributions obtained by flow cytometry. Cytometry 1: 71-77

19. Buchou T, Charollais R-H, Mester J (1988) Involvement of serum factor(s) absorbed to the dish in the response of cycloheximide-pretreated BP-A31 cells to serum pulses. Exp Cell Res 174: $411-420$

20. Cochran B, Reffel AC, Stiles CD (1983) Molecular cloning and genes sequences regulated by platelet-derived growth factor. Cell 33: 939-947

21. Greenberg ME, Hermanowski AL, Ziff EB (1986) Effect of protein synthesis inhibitors on growth factor activation of c-fos, cmyc, and actin gene transcription. Mol Cell Biol 6: 1050-1057

22. Nurse P, Bissett Y (1981) Gene required in G1 for commitment to cell cycle and in $\mathrm{G} 2$ for control of mitosis in fission yeast. Nature 292: 558-560

23. Piette J, Hirai SH, Yaniv M (1988) Constitutive synthesis of activator protein 1 transcription factor after transformation of mouse fibroblasts. Proc Natl Acad Sci USA 85: 3401-3405

24. Lau LF, Nathans D (1987) Expression of a set of growth-related immediate early genes in BALB/c 3T3 cells: coordinate regulation with c-fos or c-myc. Proc Natl Acad Sci USA 84: 1182-1186

25. Sassone-Corsi P, Ransone LJ, Lamph WW, Verma IM (1988) Direct interaction between fos and jun nuclear oncoproteins: role of the "leucine zipper" domain. Nature 336: 692-695

26. Schuermann M, Neuberg M, Hunter JB, Jenuwein T, Ryseck RP, Bravo R, Müller R (1989) The leucine repeat motif in fos protein mediates complex formation with jun/AP-1 and is required for transformation. Cell 56: 507-516

27. Chiu R, Boyle WJ, Meek J, Smeal T, Hunter T, Karin M (1988) The c-fos protein interacts with c-Jun/AP-1 to stimulate transcription of AP-1 responsive genes. Cell 54: 541-552

28. Dani C, Blanchard JM, Piechaczyck M, Sabouty SE, Marty L, Jeanteur P (1984) Extreme instability of myc mRNA in normal and transformed human cells. Proc Natl Acad Sci USA 81: $7046-7050$ 
29. Fort P, Resch J, Vie A, Piechaczyck M, Bonnieu A, Jeanteur P, Blanchard JM (1987) Regulation of c-fos expression in hamster fibroblasts: initiation and elongation of transcription and $m R N A$ degradation. Nucl Acid Res 15: 5657-5667

30. Riabowol K, Draetta G, Brizuela L, Vandre D, Beach D (1989) The cdc2 kinase is a nuclear protein that is essential for mitosis in mammalian cells. Cell 57:393-401

31. Yamashita S, Tobinaga T, Ashizawa Y, Nagayama Y, Yokota A, Harakawa S, Inoue S, Hirayu H, Izumi M, Nagataki S (1988) Glucose stimulation of protooncogene expression and deoxyribonucleic acid synthesis in rat islet cell line. Endocrinology 123: 1825-1829

32. Swenne I (1982) The role of glucose in the in vitro regulation of cell cycle kinetics and proliferation of fetal pancreatic B-cells. Diabetes 31:754-760

33. Swenne I (1983) Effects of aging on the regenerative capacity of the pancreatic B-cell of the rat. Diabetes 32:14-19

34. Rabinovitch A, Quigley C, Rechler MM (1983) Growth hormone stimulates islet $\beta$-cell replication in neonatal rat pancreatic monolayer cultures. Diabetes 32: 307-312

35. Swenne I, Hill DJ, Strain AJ, Milner RDG (1987) Growth hormone regulation of somatomedin C/insulin-like growth factor I production and DNA replication in fetal rat islets in tissue culture. Diabetes 36: 288-294

36. Otonkoski T, Knip M, Wong I, Simell O (1988) Effects of growth hormone and insulin-like growth factor I on endocrine function of human fetal islet-like cell clusters during long-term tissue culture. Diabetes 37: 1678-1683

37. Sieradzki J, Fleck H, Chatterjee AK, Schatz H (1988) Stimulatory effect of insulin-like growth factor-I on $\left[{ }^{3} \mathrm{H}\right]$ thymidine incorporation, DNA content and insulin biosynthesis and secretion of isolated pancreatic rat islets. J Endocrinol 117: 59-62
38. Welsh M, Welsh N, Nilsson T, Arkhammar P, Pepinsky RB, Steiner DF, Berggren PO (1988) Stimulation of pancreatic islet beta-cell replication by oncogenes. Proc Natl Acad Sci USA 85: $116-120$

39. Pledger WJ, Stiles CD, Antoniades HN, Sher CD (1978) An ordered sequence of events is required before Balb/c 3T3 cells become committed to DNA synthesis. Proc Natl Acad Sci USA 75: $2839-2843$

40. Swenne I, Heldin CH, Hill DJ, Hellerström C (1988) Effects of platelet-derived growth factor and somatomedin-C/ insulin-like growth factor I on the deoxyribonucleic acid replication of fetal islets of Langerhans in tissue culture. Endocrinology 122: 214-218

41. Welsh M, Claesson-Welsh L, Hallberg A, Welsh N, Betsholtz C, Arkhammar P, Nilsson T, Heldin CH, Berggren PO (1990) Coexpression of platelet-derived growth factor (PDGF) $B$ chain and the PDGF $\beta$-receptor in isolated pancreatic islet cells stimulates DNA synthesis. Proc Natl Acad Sci USA (in press)

42. Scher CD, Pledger WJ, Martin P, Antoniades H, Stiles CD (1978) Transforming viruses directly reduce the cellular growth requirement for a platelet-derived growth factor. J Cell Physiol 97: 371-380

Received: 5 March 1990

and in revised form: 7 May 1990

Dr. B.Bréant

INSERM Unité 55

Hôpital Saint Antoine

184 rue du Faubourg Saint Antoine

F-75012 Paris

France 